\title{
Effects of Some Compounds and Metals on Dill Polyphenol Oxidase Activity
}

\author{
Gulnur Arabaci
}

\begin{abstract}
Polyphenol oxidase (PPO) is a copper-containing metalloenzyme which catalyzes the o-hydroxylation of monophenols to o-diphenols and their oxidation to colored reactive o-quinones. PPO is a major enzyme, responsible for enzymatic browning reaction of damaged fruit and plant tissues. Some metals (Fe, Mn, Zn, Cu, Mg and $\mathrm{Ni}$ ) are essential for plant growth as they are involved in living processes such as photosynthesis and DNA synthesis. However, some metals (Cd, $\mathrm{Cr}, \mathrm{Sn}, \mathrm{Pb}, \mathrm{Hg}$ ) are considered to be toxic to plant and other living organisms. In the present work, PPO was isolated and characterized from dill (Anethum graveolens L.) plant grown in Sakarya, Turkey. Then, the effect of some compounds which are known anti-browning agents, amino acids, metals and metal-compound mixtures were investigated on dill PPO enzyme activity. The results showed that anti-browning agents had inhibitory effect to dill PPO activity. $\mathrm{Cu}(\mathrm{II})$ and $\mathrm{Fe}(\mathrm{II})$ metals increased the enzyme activities however, $\mathrm{Hg}$ (II), Sn(II) had the maximum inhibitory effect and $\mathrm{Zn}$ (II) and $\mathrm{Pb}(\mathrm{II})$ had no significant effect on the enzyme activity. In order to reduce the toxic effect of heavy metals, the effects of metal-compound mixtures on the PPO activity were determined. EDTA and metal mixtures had no significant effect on the enzyme. However, anti-browning compound and metal mixtures decreased the enzyme activity.
\end{abstract}

Index Terms - Anethum graveolens L., Dill, Metals, Polyphenol oxidase.

\section{INTRODUCTION}

Browning of cut or damaged surface of plants and fruits is a major problem usually resulting in negative effects on color, taste, and nutritional value in food. It is an enzymatic browning caused by an enzyme called polyphenol oxidase (PPO). Polyphenol oxidase (E.C. 1.14.18.1) is a copper containing enzyme which catalyzes hydroxylation of monophenols to ortho-diphenols (catecholase activity) and the oxidation of ortho-diphenols to quinones [1]. The quinones generated by PPO lead to the brown to black discoloration of fruits and other plant materials [2].This is a series problem for food and plant producers and customers. Because of the importance of this reaction in the food process, PPO has been intensively studied in several plants such as sorrel [3], ferula sp.[4], eggplant [5], artichoke [6], peppermint [7], mulberry [8]and red Swiss chard [9].

In recent years, there has been an increasing living systems'

Manuscript received April 26, 2016. This work was supported in part by the Sakarya University, Turkey under Grant BAP 2012-02-04-040.

G. A. Author is with Sakarya University, Department of Chemistry, Serdivan, Sakarya, 54187 Turkey health concern associated with environmental pollution by heavy metals. Heavy metals such as iron, cobalt, copper, manganese, and zinc with various amounts play important role in living organisms. However, all metals at high concentrations are toxic for plants, human and other organisms [10]. Plants show oxidative stress upon contact to heavy metals that leads to cellular damage and change in their enzyme activities involved in defense system of plants. Polyphenol oxidase is the one of these enzymes. Some studies were carried out to assess the effects of different metals and compounds (singly or in combination) on various plants in relation to their biochemical response $[3,11]$.

Although there is a study regarding characterization and purification of PPO from dill plant, no reports have been found on the biochemical properties of some compounds, metals and metal-compound mixtures on PPO enzyme from dill (Anethum graveolens L.) plant grown in Sakarya, Turkey. Therefore, the objective of our study was to isolate, characterize and investigate biochemical properties of PPO from dill by using metals, anti-browning agents and both of their mixtures.

\section{MATERIAL AND METHODS}

\section{A. Chemicals}

Dill (Anethum graveolens L.) used in this study was obtained from Sakarya, Turkey and stored at $-20^{\circ} \mathrm{C}$ until used. Polyviniylpolypyrolidone (PVP), Sephadex G-100, $\left(\mathrm{NH}_{4}\right)_{2} \mathrm{SO}_{4}$ and other chemicals were obtained from Sigma Chemical Co., St. Louis, MO.

\section{B. Enzyme extraction}

Dill (Anethum graveolens L.) plant was obtained from Sakarya city, Turkey. 10 grams of dill plants were added to 50 $\mathrm{ml} 50 \mathrm{mM}$ sodium phosphate buffer (pH; 7.0), $10 \mathrm{mM}$ ascorbic acid, 0.3 g polyvinylpolypyrolidone (PVPP), and extraction was prepared. The mixture was homogenized with blender. After the filtrate was centrifuged at $14.000 \mathrm{xg}$ for $30 \mathrm{~min}$ and supernatant was collected. Extraction was fractionated with $\left(\mathrm{NH}_{4}\right)_{2} \mathrm{SO}_{4}$, solid $\left(\mathrm{NH}_{4}\right)_{2} \mathrm{SO}_{4}$ was added to the supernatant to obtain $60 \%$ saturation. The mixture was centrifuged at $14,000 \mathrm{xg}$ for 30 minutes and the precipitate was dissolved in a small amount of phosphate buffer and then dialyzed at $4^{\circ} \mathrm{C}$ in the same buffer for $24 \mathrm{~h}$ with three changes of the buffer during dialysis. The dialyzed enzyme extract was centrifuged and loaded onto Sephadex G-100 column previously equilibrated with extraction buffer, and washed with the same buffer to remove unbound proteins. The eluate was used as the PPO enzyme 
source in the following experiments. The amount of PPO was performed according to method of Bradford with bovine serum albumin as standard [12].

\section{Enzyme assay}

Polyphenol oxidase activity was determined by measuring the increase in absorbance at $420 \mathrm{~nm}$ for 4-methylcatechol, 320 $\mathrm{nm}$ for pyrogallol substrates and $280 \mathrm{~nm}$ for L-Tyrosine. The optimum $\mathrm{pH}$ and temperatures of PPO enzyme were obtained for 4-methylcatechol and pyrogallol as substrates. For the substrate, the kinetic data was plotted as reciprocals of activities versus substrate concentrations. The Michaelis-Menten constant $(\mathrm{Km})$ and maximum velocity (Vmax) were determined from graphical evaluation of the results with Michaelis-Menten equations. To obtain the equation of a straight line and reliable results of Vmax and $\mathrm{Km}$, the Michaelis-Menten equation was converted to the double reciprocal form, known the Lineweaver-Burk plot [13].

PPO activity was determined with different substrates (4-methylcatechol, pyrogallol, and L-Tyrosine) to find the effect of $\mathrm{pH}$. Appropriate buffers $(0.1 \mathrm{M}$ citrate/0.2 M phosphate for $\mathrm{pH} 4.0-5.5,0.2 \mathrm{M}$ phosphate for $\mathrm{pH}$ 5.5-7.0, and Tris-HCl for $\mathrm{pH}$ 7.0-9.0) were used for the determination of optimum $\mathrm{pH}$ of PPO. Effect of temperature was also determined. PPO activity was measured at different temperatures in the range from 0 to $80^{\circ} \mathrm{C}$ using the substrates to determine the optimum temperature of the enzyme.

\section{Effect of some compounds, metals and metal-compound mixtures}

L-ascorbic acid, ethylenediamine tetraacetic acid (EDTA), Benzoic acid, L-Cysteine, citric acid as antibrowning agents $(0.5-1 \mathrm{mM})$ were used to determine their effects on dill PPO enzyme activities with using 4-methylcatechol as substrate at pH 7.0. $\mathrm{Fe}(\mathrm{III})$ (FeCl3), $\mathrm{Cu}(\mathrm{II})\left(\mathrm{CuSO}_{4}\right), \mathrm{Zn}(\mathrm{II})\left(\mathrm{ZnSO}_{4}\right), \mathrm{Na}(\mathrm{I})$ ( $\mathrm{NaCl}), \mathrm{Pb}$ (II) $\left(\mathrm{PbCl}_{2}\right), \mathrm{Sn}(\mathrm{II})\left(\mathrm{SnCl}_{2}\right), \mathrm{Hg}$ (II) $\left(\mathrm{HgCl}_{2}\right)$, as metals at different $(1-10 \mathrm{mM})$ concentrations were used to determine their effects on dill PPO enzyme activity with using 4-methylcatechol as substrate.

Each metal and each compound were pre-incubated separately to form metals-compound mixture for 30 minutes at $25{ }^{\circ} \mathrm{C}$. Then, the effects of mixtures on the dill PPO enzyme activities were determined by kinetic methods using 4-methylcatechol as a substrate at $\mathrm{pH}$ 7.0. The remaining enzyme activities were calculated for all compounds, the metals and metal-compound mixtures.

\section{RESUltS AND DISCUSSION}

\section{A. Enzyme Extraction and Characterization}

Polyphenol oxidase enzyme (PPO) (EC 1.10.3.2) was partially purified and kinetically characterized from dill (Anethum graveolens L.) plant grown in Sakarya, Turkey. Partially purified dill PPO enzyme was characterized by using 4-methyl catechol, pyrogallol and L-Tyrosine as substrates. Substrate saturation curves for each substrate indicated that dill PPO follows Michaelis-Menten kinetics. Lineweaver-Burk plots for the kinetic analysis of the reaction rates, at various concentrations for each substrate, showed Vmax and Km values for each substrate. The $\mathrm{Km}$ and Vmax values of dill PPO enzyme were determined according to the Lineweaver-Burk method and found to be, $1.8 \mathrm{mM}$ and $642 \mathrm{EU} / \mathrm{ml} / \mathrm{min}$ for 4-methylcatechol; and $11.5 \mathrm{mM}$ and $4103 \mathrm{EU} / \mathrm{ml} / \mathrm{min}$ for pyrogallol as substrates. No activity was detected toward L-Tyrosine. The results were consistent with the previous report on plant PPOs [7, 14].

The optimum $\mathrm{pH}$ value for dill $\mathrm{PPO}$ was determined in $\mathrm{pH}$ ranges of 3.0-9.0 (Figure 1). As seen in Figure 1, it was found that optimum $\mathrm{pH}$ values for dill PPO were 7.0, and 8.0 for 4-methylcatechol and pyrogallol as substrates, respectively. The similar optimum $\mathrm{pH}$ values for PPO enzymes from different plant sources have been reported: 7.2 for pear [15], 6.5 for madler [16], 7.0 for sorrel [3], 7.0 for red poppy leaf [17] with 4-methylcatechol as a substrate, 8.0 for sorrel [3], 8.0 for red poppy leaf [17] and 8.0 for artichoke [6] with pyrogallol as substrate.

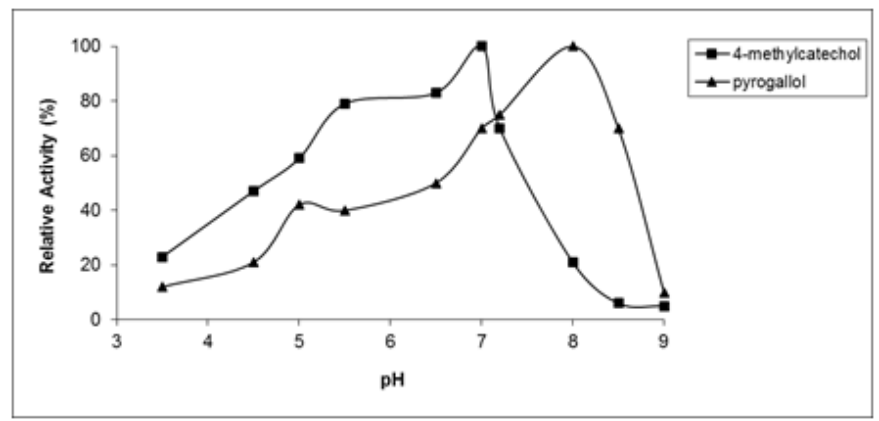

Fig. 1. Activity of dill PPO as a function of $\mathrm{pH}$ with two different substrates.

The temperature effects on dill PPO activity were studied between 5 and $80^{\circ} \mathrm{C}$ with 4-methylcatechol and pyrogallol substrates (Figure 2). It is found that the optimum temperature is $25^{\circ} \mathrm{C}$ for 4 -methylcatechol, and $40^{\circ} \mathrm{C}$ for pyrogallol. It is reported that optimum temperature for $\mathrm{PPO}$ is $25^{\circ} \mathrm{C}$ for ferula sp. [4], $30^{\circ} \mathrm{C}$ for sorrel [3], $30^{\circ} \mathrm{C}$ for lemon balm [14] and $35^{\circ} \mathrm{C}$ for red poppy leaf [17] , using 4-methylcatechol as a substrate, and $35^{\circ} \mathrm{C}$ for sorrel [3] and red poppy leaf [17], $40^{\circ} \mathrm{C}$ for lemon balm [14] using pyrogallol as a substrate.

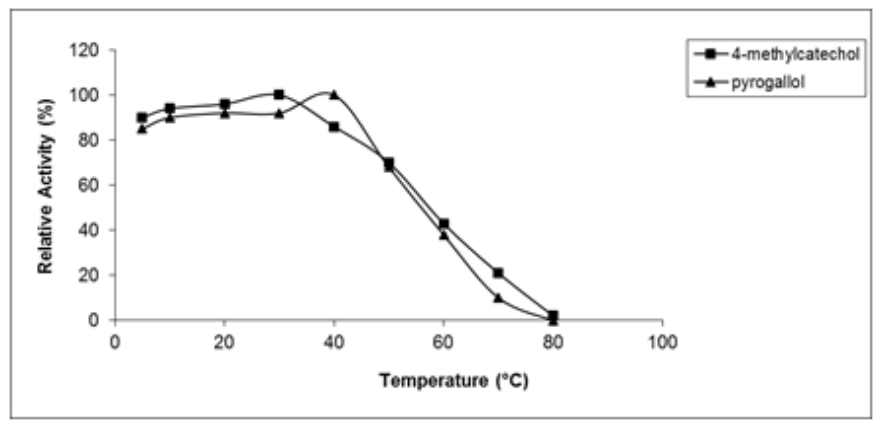

Fig. 2. Activity of dill $\mathrm{PPO}$ as a function of temperature $\left({ }^{\circ} \mathrm{C}\right)$ with two different substrates. 
B. Effect of some compounds, metals and metal-compound mixtures

Dill PPO enzyme activity was determined with various compounds and metals using 4-methylcatechol as a substrate (Table I). The results demonstrated that L-cysteine (L-Cys) was the most effective inhibitor, followed by L-ascorbic acid, EDTA, L-Arginine (L-Arg) and citric acid (CA) at $1 \mathrm{mM}$ concentration (Table I). Among the PPO intibitors, L-Cysteine and ascorbic acid are effective inhibitor for different PPOs $[6,7,18]$. Since cysteine and ascorbic acid are naturally occurring substances and non-toxic, they can be useful for preventing the enzymatic browning of dill plant. EDTA is used with an objective to bind cupper ion of PPO enzyme to prevent the binding to prostetic group ending with inhibition of enzyme activity. EDTA showed inhibition to dill PPO activity like artichoke heads [6] and Rosmarinus Officinalis L. PPO [18].

TABLE I

THE EFFECTS OF METAL AND SOME COMPOUNDS ON DILL PPO ENZYME ACTIVITY

\begin{tabular}{lcc}
\multicolumn{3}{c}{ ACTIVITY } \\
\hline \hline \multirow{2}{*}{ Metals } & \multicolumn{2}{c}{ Remaining Activity (\%) } \\
& $(1 \mathrm{mM})$ & $(10 \mathrm{mM})$ \\
\hline $\mathrm{FeCl}_{3}$ & 103 & 131 \\
$\mathrm{CuSO}_{4}$ & 100 & 115 \\
$\mathrm{ZnSO}_{4}$ & 100 & 95 \\
$\mathrm{NaCl}$ & 72 & 51 \\
$\mathrm{SnCl}_{2}$ & 25 & 3 \\
$\mathrm{HgCl}_{2}$ & 39 & 0 \\
$\mathrm{PbCl}_{2}$ & 99 & 94 \\
& & \\
Some Compounds & $(0.5 \mathrm{mM})$ & $(1 \mathrm{mM})$ \\
\hline L- Ascorbic Acid & 48 & 5 \\
EDTA & 80 & 45 \\
L-Arginine & 95 & 70 \\
L-Cysteine & 24 & 0 \\
Citric Acid & 100 & 92 \\
& & \\
\hline \hline
\end{tabular}

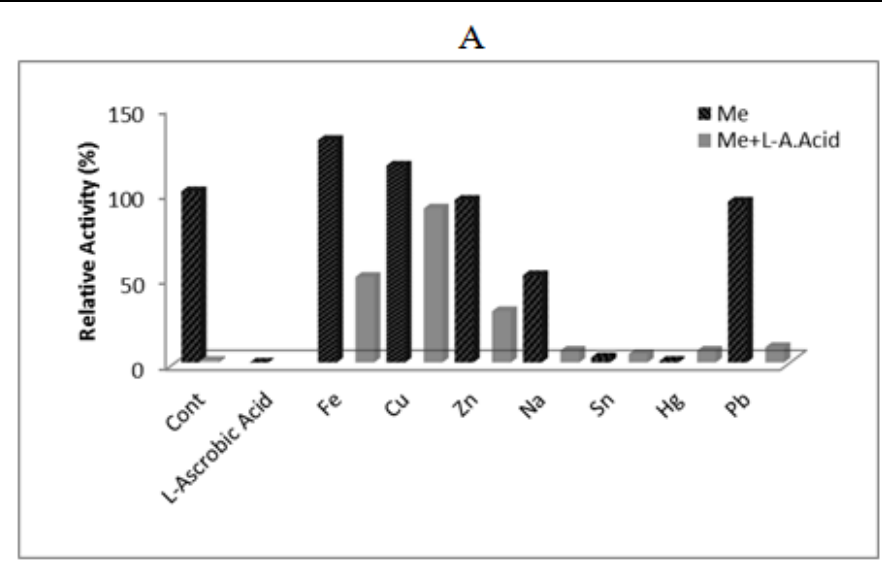

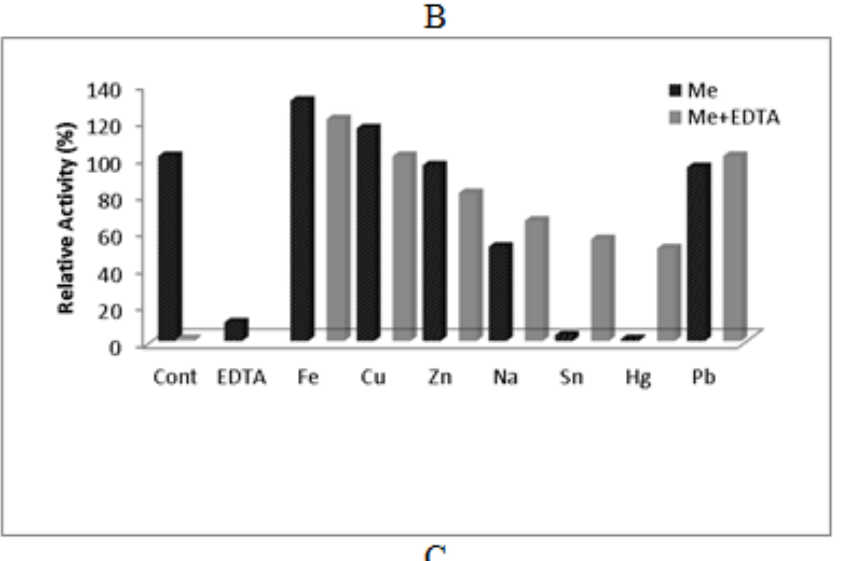
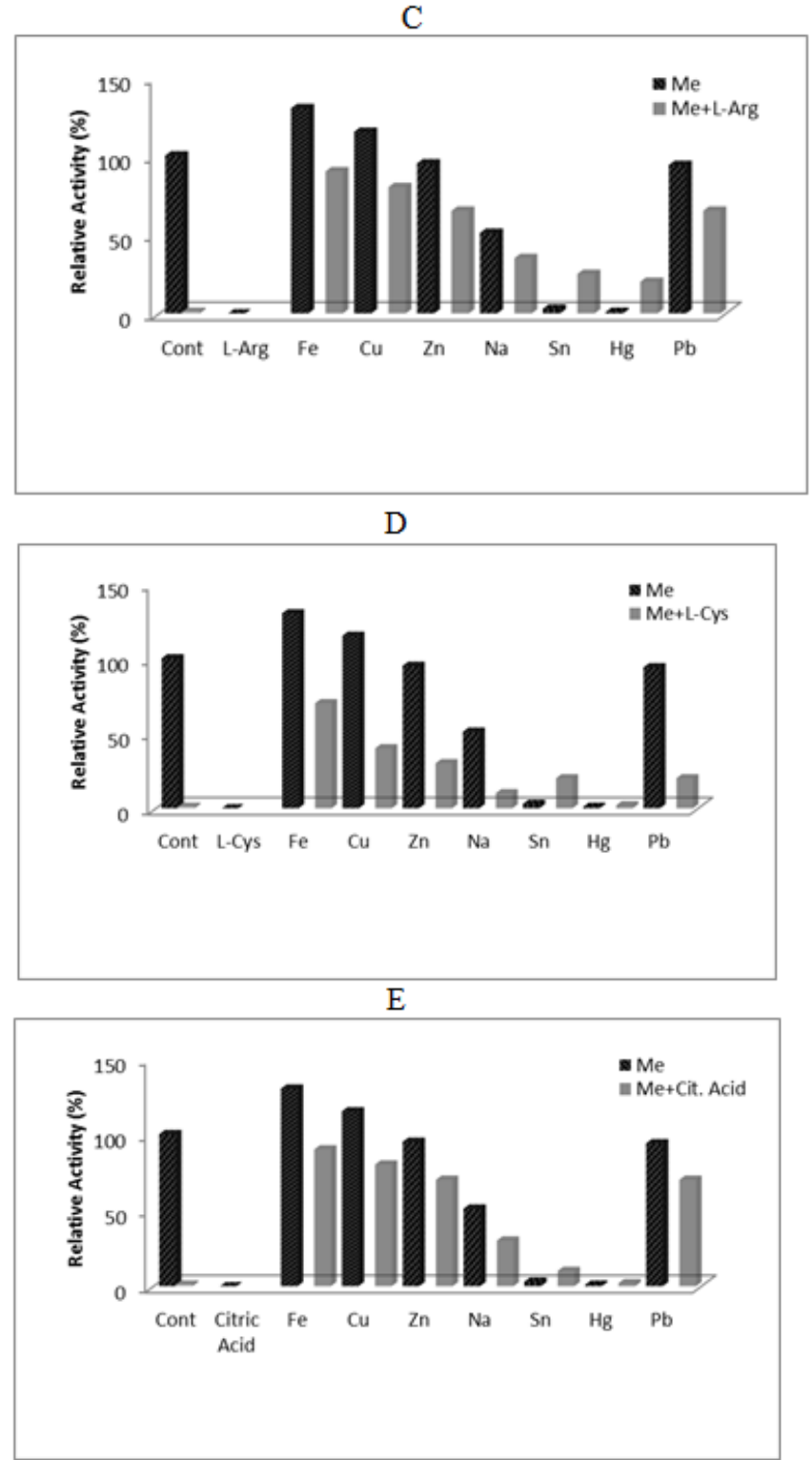

Fig. 3. Relative activity (\%) profiles for sorrel PPO against metals and compounds. (A) Metal and Metal+ L-Ascorbic Acid, (B) Metals and Metal+ EDTA, (C) Metal and Metal+ L-Arginine, (D) Metal and Metal+ L-Cysteine, (E) Metal and Metal+ Citric Acid.

Dill PPO enzyme activity was also determined with various metals at different concentrations (1-10 mM) (Table I). The enzyme was slightly inhibited some metal ions such as Zn(II) 
and $\mathrm{Pb}(\mathrm{II})$ at $10 \mathrm{mM}$ concentrations (Tale I). $\mathrm{Cu}(\mathrm{II})$ and $\mathrm{Fe}(\mathrm{II})$ metals increased the enzyme activities. Similar activation of Rosmarinus officinalis L. [6], sorrel [3], red poppy leaf [17] PPO activity were reported at the same concentrations of metals. $\mathrm{NaCl}$ is a known inhibitor for PPO enzyme from several several plants and fruits [3, 5, 6, 17, 18]. It had effective inhibition on dill PPO enzyme activity at any concentrations. Hg (II) and Sn(II) had the maximum inhibitory effect on dill PPO enzyme activity at $10 \mathrm{mM}$ concentrations.

Dill PPO activity was also determined with metal and compound mixtures [Fig. 3]. Metal and compound mixtures at $10 \mathrm{mM}$ concentrations were preincubated in $\mathrm{pH} 7.0$ buffer for 30 min. Then the effects of mixtures on dill PPO enzyme activity were determined with 4-methylcatechol as a substrate. The results showed that, EDTA and metal mixture had no significant effect on the enzyme activity. L-ascorbic acid and metal mixture decreased the enzyme activity but L-ascorbic acid-Cu(II)-mixture had no effect on the enzyme activity. L-Cys-Pb, L-Cys-Hg and L-Cys-Sn mixtures had inhibitory effect respectively but the other L-Cys-metal mixtures had no effect on the enzyme activity. L-Arg-metal and citric acid-metal mixtures had weak inhibitor effect on the enzyme activity. The results showed that the metal-antibrowning compound mixtures may increase the inhibitory effect of anti-browning mixtures for the enzymatic browning in fruits and vegetables. The mixtures may also reduce the toxic effect of heavy metals in plants.

\section{CONCLUSION}

In this work, PPO enzyme was extracted and characterized from dill (Anethum graveolens L.) plant grown in Sakarya, Turkey. The substrate specificity indicated its nature as a catechol oxidase (EC 1.10.3.2), showing maximum activity with 4-methyl catechol. The enzyme did not have tyrosinase activity. Some metals and antibrowning compounds were kinetically investigated for dill PPO activity. Some metals (Cu(II) and $\mathrm{Fe}(\mathrm{II})$ ) increased the enzyme activity, the rest of tested metals decreased the activity. All tested anti-browning agents had inhibitory effect to dill PPO activity. The effects of metal-compound mixtures on the PPO activity were also determined. EDTA and metal mixtures had no significant effect on the enzyme. However, all anti-browning compound and metal mixtures inhibit dill PPO enzyme. The results suggests that the mixtures can reduce toxic effect of heavy metals for plants. This might prevent plants, grown in heavy metal polluted environment.

\section{ACKNOWLEDGMENT}

This research was financed by Scientific Research Foundation of Sakarya University, Turkey (Project No.BAP 2016-02-04-008).

\section{REFERENCES}

[1] M. R . Marshall,. and R. Yoruk, "Physicochemical properties and function of plant polyphenol oxidase: a review," J. Food Biochem. Vol. 27, pp. 361-422, 2003.

http://dx.doi.org/10.1111/j.1745-4514.2003.tb00289.x
[2] L. Vamos-Vigyazo, "Polyphenol oxidase and peroxidase in fruits and vegetables,”CRC Crit. Rev. Food Sci. Nutr. Vol. 15, pp. 49-127, 1981 http://dx.doi.org/10.1080/10408398109527312

[3] G. Arabaci, "Effects of Metals and Anti-browning Agents on Polyphenol Oxidase Activity from Sorrel (Rumex acetosa),” IJISET - International Journal of Innovative Science, Engineering \& Technology, vol. 2,no. 12, pp. 832-837.

[4] M. Erat, H. Sakiroglu, and I. O. Kufrevioglu, "Purification and characterization of polyphenol oxidase from Ferula sp.," Food Chemistry, vol. 95, pp. 503-508, 2006. http://dx.doi.org/10.1016/j.foodchem.2005.01.044

[5] S. Fujita, and T. Tono, "Purification and some properties of polyphenoloxidase in eggplant (Solanum melongema)," Journal of Science and Food Agricultural, vol. 46, pp. 115-123, 1988. http://dx.doi.org/10.1002/jsfa.2740460111

[6] T. Aydemir, "Partial purification and characterization of polyphenol oxidase from artichoke (Cynara scolymus L.) heads”. Food Chemistry, vol. 87, pp. 59-67, 2004. http://dx.doi.org/10.1016/j.foodchem.2003.10.017

[7] D. Kavrayan, and T. Aydemir, "Partial Purification and Characterization of Polyphenol Oxidase from Peppermint (Mentha piperita)", Food Chemistry, vol. 74, pp. 147-154, 2001. http://dx.doi.org/10.1016/S0308-8146(01)00106-6

[8] O. Arslan , M. Erzengin, S. Sinan, and O. Ozensoy, "Purification of mulberry (Morus alba L.) polyphenol oxidase by affinity chromatography and investigation of its kinetic and electrophoretic properties," Food Chemistry, vol. 88, no. 3, pp. 479-484, 2004. http://dx.doi.org/10.1016/j.foodchem.2004.04.005

[9] Z. J. Gao, X. H. Han, and X. G. Xiao, "Purification and characterisation of polyphenol oxidase from red Swiss chard (Beta vulgaris subspecies cicla) leaves," Food Chemistry, vol. 117, pp. 342-348, 2009. http://dx.doi.org/10.1016/j.foodchem.2009.04.013

[10] R. Singh, N. Gautam, A. Mishra, and R. Gupta, "Heavy metals and living systems: An overview," Indian Journal of Pharmacology, vol.43, no. 3, pp. 246-253, 2011. http://dx.doi.org/10.4103/0253-7613.81505

[11] R. Chandra, R.N. Bhargava, S. Yadav, and D. Mohan, “Accumulation and Distribution of Toxic Metals in Wheat (Triticum aestivum L.) and Indian Mustard (Brassica campestris L.) İrrigated with Distillery and Tannery Effluents”, J. Hazard. Mater, vol. 162, pp. 1514-1521, 2009. http://dx.doi.org/10.1016/j.jhazmat.2008.06.040

[12] M. A Bradford, "A rapid and Sensitive Method for the Quantitation of Microgram Quantities of Protein Utilizing the Principle of Protein-dye Binding”, Analytical Biochemistry, vol. 72, pp. 248-254, 1976. http://dx.doi.org/10.1016/0003-2697(76)90527-3

[13] H. Lineweaver, and D. Burk, "The Determination of Enzyme Dissociation Constants”, Journal of the American Chemical Society, vol. 56, pp. 58-666, 1934. http://dx.doi.org/10.1021/ja01318a036

[14] S. Dogan, Y. Ayyildiz, M. Doğan, Ü. Alan and M. E. Diken, "Characterisation of polyphenol oxidase from Melissa officinalis L. subsp. officinalis (lemon balm)”, Czech J. Food Sci., vol. 31, no. 2, pp. 156-165, 2013.

[15] E. Ziyan, and S. Pekyardımc1, "Purification and Characterization of Pear (Pyrus communis) Polyphenol Oxidase”, Turk. J. Chem., vol. 28, pp.547 $-557,2004$.

[16] B. Dincer , A. Colak , N. Aydin, A.Kadioglu, S and Guner, "Characterization of polyphenoloxidase from medlar fruits (Mespilus germanica L., Rosaceae)”, Food Chemistry, vol.77, pp.1-7, 2001. http://dx.doi.org/10.1016/S0308-8146(01)00359-4

[17] G. Arabaci, "Investigations of Metals and Metal-Antibrowning Agents Effects on Polyphenol Oxidase Activity from Red Poppy Leaf," International Journal of Biological, Food, Veterinary and Agricultural Engineering, vol. 9, no. 1, pp.1-5, 2015.

[18] T. Aydemir, "Selected Kinetic Properties of Polyphenol Oxidase Extraxted from Rosmarinus Officinalis L.," International Journal of Food Properties, vol. 13, pp. 475-485, 2010.

http://dx.doi.org/10.1080/10942910802641993 